\title{
Improving Class Interaction Using Hand-Made Wordless Picture Series for Preschoolers during Storytelling
}

\author{
Yustina Laurentius Sri Mulatsih ${ }^{1}$, Muhammad Hanif ${ }^{2}$, Suharno ${ }^{3}$, Sri Anitah ${ }^{4}$ \\ 1,2,3,4 Depatment of Educational Technology, Faculty of Teacher Training and Education \\ Universitas Sebelas Maret \\ Email: mulatsih@student.uns.ac.id
}

(Received: January-2018; Reviewed: February-2018; Accepted: March-2018; Published: March-2018) access under license CC BY-NC-4.0 (https://creativecommons.org/licenses/by-nc/4.0/).

\begin{abstract}
Early childhood is critical period for language development. Children need more language interactions with caregivers, to optimize its development. Language interactions become the most powerful point to language development. Prior research shows that storytelling promotes preschoolers' language production and interaction. However, little is known about the potential role of wordless picture series books to encourage interaction. Comparing to books with text, wordless picture books can foster more spontaneous language production and teachers' feedback. The objective of this study was to find out the difference of classroom interactions level of twenty preschoolers to their teachers during storytelling measured by using Classroom Assessment Scoring System (CLASS). The experimental method used to compare those variables in experimental and control class. The material used were a wordless picture series book which is hand-made by teachers and a story book with text. The findings showed that in the wordless picture series book condition teachers showed higher levels of instructional support than a story book with text. The result revealed a significant improvement of teachers' quality of feedback during storytelling instruction. It was proofing that wordless picture series books may boost classroom interaction and finally support language development of preschool students.
\end{abstract}

Keywords: class interaction; wordless picture book; storytelling.

\section{INTRODUCTION}

Preschooler education is essentially an education organized to facilitate the growth and development of early-aged children personality (Lestari \& Prima, 2017). Preschooler education aims to develop various aspects of basic development in early age including moral values, physical psychomotor, cognitive, language, and artistic aspects. Those aspect should be provided comprehensively into learning activities. Language skills enable a child to communicate with others in his or her environment, which promotes socio-emotional regulation through social interactions. Thus, language learning is crucial for a child's developmental (Zauche, Thul, Mahoney, \& Stapel-Wax, 2016).

In many Indonesian kindergarten, teachers only promote language acquisition by introducing letter, word and sentence using dictation method. Some of them use storytelling using a story book facilitated by the educational authority. Those condition is also found in several kindergarten schools in Sragen regency. Those facts was problematic since dictation will only address the cognitive developments. For those who use storytelling, less interaction in 
class resulted a chaos activity. One way interaction bored the students and then made them lost of concentration.

The language acquisition is gained by the social interactions between children and their teachers or caregivers (Hirsh-Pasek \& Golinkoff, 2012). Children language environment, weather at home or in school influences certain differences of the acquisition. Even though the input language children receive at home are supposed to be more influencing, language instruction from teachers at school in a very early age also be significantly under consideration since the hours of interaction that children receive outside their homes is now rising. In this study, we explore an alternative way to improve teacher-children interactions in a national kindergarten school of Indonesia.

Many types of interactions, especially conversational, are believed to promote children language acquisition (Milburn, 2014). In class situation, children are exposed to listen to the instruction and produce their own language forms, and teachers respond by providing feedback to children's productions. In preschool, teachers' input influences on children's language as well as parents did at home. Teachers' talk predicts the complexity of children's language productions and comprehension (Justice, 2008).

Furthermore, the quality of interactions between teacher and children in classrooms plays a significant role in language acquisition especially for early-aged-student. Storytelling is believed can enrich class interactions where teachers who are highly elaborative with spontaneous story will facilitate the use of more complex language in children.

In terms of interaction, the ways in which teachers provide instructional support become the point of issues. This study emphasized two dimensions of instructional support in form of teachers' practices to facilitate and encourage students' language (Language Modeling dimension) and teachers' practices to provide feedback to promote learning (Quality of Feedback dimension) (La Paro, 2004). Class with high-quality interactions will provide functional instructions to children and explicitly teach their student language abilities (Justice, 2008).

Story telling is one of the main forms of complex comunication through which events are organised. The production of a language during story telling involves interpretation of meaning, and also the organisation of this information in a coherent form. Despite their complex nature, children are exposed to retell a story from an earlyage as they are involved in simple activities such as talking about past events, watching TV shows, and sharing books and stories at home or in school. The ability to understand and produce a story develops before children begin to introduce reading. Story telling competence is related to school success to provide a chance and develop narrative competence (Silva, Strassera, \& Cain, 2014). Therefore, it is important to determine how we can foster narrative growth in the early years.

Storytelling is a technique where teacher or caregiver retell a story in front of class while getting children in conversation. This activities can foster class interactions and boost preschoolers' language skills. In addition, while telling stories, teachers scaffold children by providing information about what is valued and should be included in narratives story (Silva, Strassera, \& Cain, 2014). It has been shown that caregivers provide an enriched linguistic input during storytelling compared to other activities because language in texts is more complex and diverse than parents' spontaneous utterances (Montag, 2015).

The effect of systematic storytelling on pre-schooler language comprehension and language production is strongly positive. Listening to a story read aloud helps students to develop the habit of listening. At the same time, while listening to a story students will get a specific training in comprehension through exposure to the interesting and meaningful content of the stories.

One of the reasons for using the technique of storytelling in the classroom is that it allows the modeling of language patterns. Learners can imitate the structure and the sounds they hear. While the teacher is reading, students can infuse the syntactic order of the written language with teachers body language cues that contribute to the interpretation of the story meaning. (Al-Mansour \& Al-Shorman, 2011). Imitation of the sounds has a direct bearing on the increased vocabulary that is a result of hearing stories and poems. Hearing words in context adds to the number of meanings in a learner's receptive vocabulary and gives the listener alternative ways to express him or herself. Stories also introduce new vocabulary 
and language forms with rich networks of associations. Moreover, stories can have a deep impact on a person's construction of knowledge.

During storytelling activity, book genre specifically influences the complexity of language productions. A certain type of genre may foster longer sentences, words and greater variability of verbal tenses, when compared to others. In addition to its genre, picture series contained in a book influence different class interactions and language production in early aged-children. A book with picture series is believed can force teacher and student produce more words even though still follow the text provided (Chaparro-Moreno, Reali, \& Maldonado-Carre no, 2017). Wordless picture series books which do not have words containing and point to the series of images as way conveying the meaning and the function of story. Unlike retelling story with other media, wordless picture series books make the teachers and students has to make meaning from the images only. Wordless picture series books increase the active participation of the listener because they are more actively to construct meaning (Arizpe, 2013).

Some related theories stated above makes the wordless-picture series book can be an alternative solution to potentially support language development of preschoolers in schools context. Based on those condition above, this study aims to investigate the use of wordless-picture series book in storytelling to enhance class interaction compared to story book with text.

\section{METHOD}

This research investigates the significant different of classroom interaction a wordless picture series book compared to storybook with text in storytelling session. Storytelling sessions were conducted in a sample of three classes from three different national kindergarten school in Sragen Regency. Each classes consist of two teachers paired with groups of ten children. Every classes retell a story from both wordless picture series and text books in different sessions. The wordless picture series book used is a hand-made drawing entitled Gurit Bermain by the researcher, while the book with text used is Kancil yang Cerdik facilitated by the Ministry of National Education. Both of them brings the theme of friendship with animal icon. The wordless picture series use a Squid (gurita) as main character in a setting of underwater, while the book with text use a deer (kancil) as main character in forest situation. Those book is chosen because of having the same criteria of containing six pages and a picture in each pages.

To measure the quality of classroom interaction was used the Classroom Assessment Scoring System (CLASS) (La Paro, 2004). Considering the complexity of interaction between teacher and student in kindergarten, we used only two dimensions of the Instructional Support domain in this study (Language Modeling and Quality of Feedback). Language Modeling, assesses the quality of teacher's techniques to stimulate and facilitate language (e.g., use of frequent conversations and advance language. Quality of Feedback, assesses teacher's feedback to promote understanding and continued participation (e.g., use of frequent feedback loops, ask students to explain their thinking, and provide additional information to expand students' understanding). Each dimension was rated on a 7-point scale ranging from low to high quality by three raters, and the domain score was calculated by averaging the two dimensions. The classification over 7 ratings, 1 and 2 correspond to low levels, 3-5 correspond to moderate levels, and 6 and 7 correspond to high levels ratings The different between average score was compared using $\mathrm{t}$ test to see the significance.

\section{RESULTS AND DISCUSSION}

\section{Results}

The instructional support rated from the two media situation of learning results is as follow 
Table 1. Rating Score of Teacher Instructional Support

\begin{tabular}{|c|c|c|c|c|c|c|c|c|}
\hline \multirow{3}{*}{$\begin{array}{l}\text { Teacher } \\
\text { Number }\end{array}$} & \multicolumn{4}{|c|}{ Using text book } & \multicolumn{4}{|c|}{ Wordless book } \\
\hline & \multicolumn{3}{|c|}{ Rater } & \multirow{2}{*}{ Mean } & \multicolumn{3}{|c|}{ Rater } & \multirow{2}{*}{ Mean } \\
\hline & I & II & III & & I & II & III & \\
\hline 1 & 3 & 3 & 2 & 2.67 & 4 & 3 & 3 & 3.33 \\
\hline 2 & 3 & 2 & 2 & 2.33 & 3 & 3 & 3 & 3 \\
\hline 3 & 2 & 3 & 2 & 2.33 & 4 & 3 & 4 & 3. 67 \\
\hline 4 & 2 & 2 & 2 & 2 & 3 & 2 & 4 & 3 \\
\hline 5 & 4 & 3 & 3 & 3.33 & 3 & 3 & 3 & 3 \\
\hline \multirow[t]{2}{*}{6} & 2 & 2 & 2 & 2 & 4 & 3 & 3 & 3.33 \\
\hline & & & & 2.44 & & & & 3.22 \\
\hline
\end{tabular}

Based on the table, we found that teachers instructional supports in storytelling activity using book with text categorized as low (mean=2.44). This result indicated that teachers rarely provided feedback and promoted children's active participation. They also rarely encouraged discussions and other activities to foster students' understanding.

In other hand, teachers instructional supports in storytelling activity using wordless book categorized as moderate (mean $=3.22$ ). This result indicated that teachers actively provided a proportional feedback and try to gain children's active participation. The teachers sometimes find a silence students but they use other technique to solve that situation. They also encouraged more repetition and other activities to ensure students' understanding.
Explicitly, almost all teachers have a greater number of ratings when used the wordless book (except teacher number 5). The teacher number 5 have a decreasing rating from 3.33 to 3 average mean. The most increasing ratings of teachers' feedback was teacher number 3 and teacher number 6 which 1.33 points increasing ratings after using wordless book. Thus, teacher number 4 have an increasing ratings of 1 point followed by teacher number 1 and techer number 2 with 0.66 points increasing ratings.

All of those teachers have a different performance during teaching activity. There was no teachers have a same level or score and identically improvement after using wordless picture series book in storytelling activity. The consistency of margin rating score showed that the reliability of the instrument was confirmed.

Table 2. Statistical of Teacher Instructional Support

\begin{tabular}{cccc}
\hline Types of book & Mean & N & Std. Deviation \\
\hline TEXT & 2.4444 & 6 & .50185 \\
WORDLESS & 3.2222 & 6 & .27217 \\
\hline
\end{tabular}

In the table 1 we also found that each raters gave intact numbers indicating that from those two dimension they gave a same score rating. When the two dimensions were compared separately, we found that during wordless book storytelling, teachers used more strategies and techniques to foster children's understanding and provided more feedback to promote understanding and continued participation. 
Table 3. T-test of Teacher Instructional Support

\begin{tabular}{|c|c|c|c|c|c|c|c|c|c|}
\hline & & \multicolumn{5}{|c|}{ Paired Differences } & & & \multirow[b]{3}{*}{ Sig. (2- } \\
\hline & & & & & $95 \% \mathrm{C}$ & fidence & & & \\
\hline & & & & $\begin{array}{l}\text { Std. } \\
\text { Error }\end{array}$ & $\begin{array}{r}\text { Interv } \\
\text { Diff }\end{array}$ & $\begin{array}{l}\text { of the } \\
\text { ence }\end{array}$ & & & \\
\hline \multirow[b]{2}{*}{ Pair 1} & & Mean & SD & Mean & Lower & Upper & $\mathrm{t}$ & $\mathrm{df}$ & tailed) \\
\hline & $\begin{array}{c}\text { TEXT - } \\
\text { WORDLESS }\end{array}$ & -.77778 & .62063 & .25337 & -1.42909 & -.12646 & -3.070 & 5 & .028 \\
\hline
\end{tabular}

With degree of freedom $=5$, t-test result revealed that teachers' instructional support was significantly different in those two situation (sig. 0.028). The wordless book session have higher level of teachers' instructional support than teaching session using book with text $(\mathrm{p}<0.05)$.

Overall, this result is consistent with studies that suggest that wordless picture books encourage class in active engagement and promoting higher levels of instructional support. As stated before that the main goal of this study was to investigate the effect of wordless-picture books on class interaction in form of teachers' instructional support. The results definitely showed that using a wordless picture book during storytelling activity gave more positive influences to the class interaction compared to texted-word book in form of teachers' levels of instructional support. In short teachers gave more helping instruction during storytelling activity.

Using a wordless picture book can improve levels of quality in class interactions higher when compared to book with text. A possible explanation is that students may engage more actively in the process of meaning construction because the story is not explicitly verbalized. When retelling story using wordless picture book, teachers and students were involved in longer conversations and give clearly response in students' talk. Those situations make teacher usually followed-up children's comments by answering their talk and repeating the story. This kind of feedback contributes to increase instructional support scores.

In addition, the pictures in wordless book give a wider range of understanding than texted-story book, therefore the situation force the teachers to give more construction of meaning in form of talk or other activity. Comparing the effect of wordless picture books to the books with text on instructional support was giving an alternative view for teacher to use an appropriate supportive media in storytelling activity. This result is important since higher levels of quality of feedback foster students' understanding.

Moreover, the use of story book with text was not directly ovoided. The story book also can be great tool to help students in certain age period. The use of story book should be combined with other classroom activity so that students was not only listening to or reading but also supported with activity to gain student and interaction such as questioning, eliciting or giving a challenging quizzes.

Retelling a story from book with text to students presents endless opportunities for related activities such as classroom discussions, role plays, shared readings, group writings, arts and crafts, and songs. It also indicated that story telling with book with text provide many types of literacy support for children. Students can learn about literacy through an adult who provides a model of retelling.

A combination of a wordless picture series book with other media is also potentially to be excuted. For example, those two media can be used as an integrated media with graded user. In very early age students, wordless would be a beneficial to built basic interest on storytelling. Then for the follow up session, a story book with text can be an advance tool to gain students understanding by reading aloud a sentence and introducing a letter by dictation method.

Giving a chance to practice to the students to use the book is also can investigated further. Giving a real experience to reteling a story will take more intention and interaction toward other students. Shifting a role to be a listener can help teacher to invite initial spoken responses from students.

\section{CONCLUSSION AND SUGGESTION}

Comparing to books with text, wordless picture books is believed can foster more 
spontaneous teachers' feedback. The wordless picture series books which were hand-made by teachers were positively can improve the class interaction. The result revealed a significant improvement of teachers' quality of feedback during storytelling instruction. In conclusion, it was found that in the wordless picture series book condition teachers showed higher levels of instructional support than book with text. It was proofing that wordless picture series books may boost classroom interaction and finally support language development of preschool students.

Our findings may have important implications for educational settings, especially for teachers who intend to use storytelling technique to develop students' language. Thus, for future research that address this area, it would be interesting to explore the language productions, as well as the nature of class interactions, during storytelling that may involve intend participation and gained interaction

\section{REFERENCES}

Al-Mansour, N. S., \& Al-Shorman, R. A. (2011). The effect of teacher's storytelling aloud on the reading comprehension of Saudi elementary stage students. Journal of King Saud University - Languages and Translation Vol. 23, 69-76.

Arizpe, E. (2013). Meaning-making from wordless (or nearly wordless) picture books: What educational research expects and what readers have to say. Cambridge Journal of Education, 43(2), 163-176.

Chaparro-Moreno, L. J., Reali, F., \& Maldonado-Carre no, C. (2017). Wordless oicture books boost preschoolers' language production during shared reading. Early Childhood Research Quarterly Vol. 40, 52-62.

Hirsh-Pasek, K., \& Golinkoff, R. M. (2012). How babies talk: Six principles of early language development. In S. Odom, E. Pungello, \& N. Gardner-Neblett (Eds.), In Re-visioning the beginning: The implications of developmental and health science for infant/toddler care and poverty (pp. 77-101). New York, NY: Guilford Press.
Justice, L. M. (2008). Quality of language and literacy instruction in preschool classrooms serving at-risk pupils. Early Childhood Research Quarterly, 23, 51-68.

La Paro, K. M. (2004). The classroom assessment scoring system: Findings from the pre kindergarten year. The Elementary School Journal, 104(5), 409-426.

Lestari, P. I., \& Prima, E. (2017). The Implementation of Traditional Games to Improve the Social Emotional Early Childhood. Journal of Educational Science and Technology, Vol. 3 No. 3, 178- 184.

Milburn, T. F. (2014). Enhancing preschool educators' ability to facilitate conversations during shared bookreading. Journal of Early Childhood Literacy, 14(1), 105-140.

Montag, J. L. (2015)). The words children hear: Picture books and the statistics for language learning. Psychological Science, 26,(9), 1489-1496.

Silva, M., Strassera, K., \& Cain, K. (2014). QuarterlyEarly narrative skills in Chilean preschool: Questions scaffold the production of coherent narratives. Early Childhood Research Quarterly Vol. 29, 205-213.

Zauche, L. H., Thul, T. A., Mahoney, A. E., \& Stapel-Wax, J. L. (2016). Influence of language nutrition on children's language and cognitive development: An integrated review. Early Childhood Research Quarterly, 36, 318-333. 